\title{
The Determinants of Income Inequality in Europe: Do Trade Liberalisation and Financial Liberalisation Matter?
}

\author{
Saad Buba, Suryati Ishak, Muzafar Shah Habibullah, Zaleha Mohd Noor \\ University Putra Malaysia, Malaysia \\ Email: saadbubadamare12@gmail.com
}

Received: December 27, 2018; Accepted: February 13, 2019; Published: March 31, 2019

Permalink/DOI: http://dx.doi.org/10.17977/um002v11i12019p040

\begin{abstract}
This study provides evidences about the determinants of income inequality in 31 sampled countries of Europe. Prior to implementing the empirical research, the study identifies the factors, which according to theories affect the level of income inequality. Income inequality is now an issue bordering not only the developing countries but also the emerging and the developed ones as well. The results obtained from the estimated model enabled to draw some interesting conclusions. Firstly, quality of the rule of law determines income inequality; secondly, trade liberalisation conditions income; thirdly, level of financial development determines inequality of income and finally, education level in emerging countries decreases the level of income inequality while increasing the level of inequality in the developed countries of the continent.
\end{abstract}

Keywords: Income Inequality; Trade Liberalisation; Financial Liberalisation; Rule Of Law; Pooled Mean Group

JEL Classification: B27

\section{INTRODUCTION}

In recent years, income inequality has become an issue worrying not only the less developed and the developing countries but the emerging and the developed ones as well. It has been increasing in most countries of Europe including the developed ones. In 2013, the Gini index for Turkey (although an emerging country) was 0.43, which is relatively high. The developed countries used in this study like the U.K, France, Luxemburg, Sweden, and Italy among others, have income disparity issue. Other countries behind Turkey are Bulgaria with 0.354 (35.4\%), Latvia, Lithuania, Greece, Portugal with 0.352 (35.2\%), 0.346 (34.6\%), 0.344 (34.4\%), and 0.342 (34.2\%), respectively. According to Eurostat (2015), most of the sampled countries were unable to moderately reduce inequality between 2004 and 2014. The Gini index runs from 0 to 1 , where 0 means full income distribution equality, 1 is maximum income distribution inequality. The OECD report (2015) decries the increasing income inequality, stating that the top income earners in the developed countries earn almost ten times more than those at the bottom of the income scale. The average GINI index for 31 sampled countries was $0.30(30 \%)$ in 2004, while in 2014 it was 0.31 (31\%). 
In Europe, the richest countries (UK, France, Italy, and Germany) tend to have relatively higher income disparity and become more unequal. UK and Italy had an average income inequality nearly 0.31 in 2013. Since 2006, Latvia, Portugal, Romania, Denmark, Italy, Lithuania and a number of other European countries have been experiencing an increase in their Gini index, (World Bank Report, 2016).

The possible outcomes associated with inequality are obvious; the young people, especially those who felt marginalized, will eventually become the easy fodder for conflicts. This will destabilise our democracies and hinder sustainable economic growth (World Economic Forum, 2015). The growing income inequality can also generate social unrest as wealth is increasingly absorbed by the few, leaving the rest of the population to fight for bits and pieces of the wealth.

Based on the arguments posed by Fredriksen (2012), this study considers macroeconomic variables such as trade and financial liberalisation and will determine their impacts on the level of income inequality in Europe, three other control variables such as the real GDP per capita growth, level of educational attainment and the rule of law were also considered. Although, recent theoretical models have suggested that trade liberalisation might reduce crime through its negative effect on income inequality. However, the effect of trade liberalisation differs in labour and capital abundant countries. A study by Ghosh et al. (2011) discovered that a higher degree of trade liberalisation tends to increase burglaries and thefts in labour abundant countries through its effect on the distribution of income while in capital abundant countries it has small negative effect on income inequality. Trade across borders of countries has a great meaning for nations to promote their economies and improve the standard of living (WTO, 2007).

For more than a decade, Europe has been pursuing trade liberalisation through regional, multilateral and bilateral initiatives. The World Trade Organization (WTO) in 2002 reported that European region upheld all (except agriculture and textiles) markets largely open, (WTO, 2002), it also maintained internal economic integration. This policy review on trade by Europe came after the support to producers by the Organisation for Economic Co-operation and Development declined by 10 percent in just one year (1999 - 2000). Most of the countries in Europe recorded a tremendous increase in gains from trade as the share of trade to GDP increased during the period 2003 - 2013. This might be as a result of liberalisation process occurred in Europe in recent years.

As a result of the increase, the value of trade between the EU-28 with the rest of the world stood at EUR 3,517 billion in 2015, (Eurostat, 2016). Trade surpluses increased to EUR 64 billion in 2015 from EUR 11 billion in 2014. Trade between the EU Member States, on the other hand, was estimated EUR 3,070 billion in 2015, 71 percent higher than the level recorded for exports to non-EU member countries, (Eurostat, 2016). In Europe, liberalisation as tariff reduction on primary and manufactured products has triggered a massive increase in the trade gains; the share of trade to GDP in the sampled countries rose by about 50 percent between 1993 and 2014. The bulk of the increase is from the northern and western countries of the continent. Tariff on manufactured goods declined by 54 percent in EU-28 countries while tariff on raw materials or primary products dropped by 59 percent in the EU area. 
This enhances both domestic and foreign trades (WDI, 2016). The question to be asked here is whether these benefits derived from the trade were evenly distributed. If not, then the level of income inequality in the continent may be undermined. The first objective of this study, therefore, is to examine the impact of trade liberalisation on income inequality in Europe.

Financial institutions and financial markets, on the other hand, are usually regulated with some restrictions. When these restrictions are eliminated, we have a liberalized financial sector. Financial liberalisation occurs when some innovations in the financial markets are made. For example, the introduction of subprime mortgage loans. In Europe, financial markets and financial system are quite liberalised, especially in the Nordic and western European countries. According to the Chinn-Ito index of financial liberalization measured in the range of $0-1$, all the 17 countries used in this study from the northern and western Europe with the exception of Iceland have an index of 1 throughout the study period. This means that countries in these parts of Europe have a financial system that is fully liberalized. In the southern and eastern part of Europe mainly referred to as the emerging countries except Italy, Spain and Portugal have Chinn-Ito index of financial liberalisation less than one, (The Chinn-Ito Index, 2017). The Chinn-Ito index measures a country's degree of capital account openness and it is based on dummy variables reported in the annual report on exchange arrangements and exchange restrictions (AREAER) of the IMF that codify the tabulation of restrictions on cross-border financial transactions.

The expectations of this study are that financial liberalisation will have a negative effect on income inequality so as to show that financial openness reduces the level of disparity of income distribution across the 31 sampled countries but might not necessarily reduce inequality of income distribution in the northern and western Europe. This is because too much financial liberalisation according to researchers may lead to inequality of income distribution, for example, in the United States, Germany and India, financial liberalisation has steered a substantial growth in income inequality, (Evans, 2014). In America, the financial liberalisation that took place in the 1980s and 1990s have expanded the financial institutions, leading to the payment of high top salaries, leaving the non-financial sector cutting costs and raising returns that eventually led to inequality problem in the US. The reforms in the highly regressive labour market in the 2000s in Germany with the greater role being given to financial markets in the 1990s have also led to increase in inequality. In India, the regulation of the financial system in the 1990s which shifted the priority programmes of the financial institutions aimed at rural areas to providing finance to business sectors, has led to a remarkable increase in income inequality. This study uses Chinn-Ito index as a measure of financial openness, it is an index measuring a country's degree of capital account openness.

The Standard theory of international trade embodied in the Hecksher-Ohlin and Stopler Samuelson theorems, simply puts the same point in a context of cross-border exchange. When trade opens between a capital-abundant and a labor-abundant country, inequality increases in the former (which, by importing labor-intensive goods, has tapped into a larger pool of labor) and diminishes in the latter (which, by importing 
capital intensive goods and services, has effectively increased its supply of capital). Similarly, any technological change that increases the relative importance of capital in production - that raises the value of $\alpha$ - lowers the wage-rental ratio and increases inequality. By contrast, any change that makes labour relatively more productive (decreases $\alpha$ ) would make for greater equality that is an increased wage-rental ratio.

Our model will assess the impacts of trade and financial liberalisation on Income Inequality in 31 European countries: 14 countries from Eastern and Southern part and 17 countries from Northern and Western part of the continent. Other control variables considered by this study are level of education attainment and economic growth.

Earlier research conducted by Stopler and Samuelson (1941) suggest that the merits of trade liberalisation are unlikely to happen in practice. Stopler and Samuelson based their argument on Hecksher-Ohlin model developed in the 1930s that trade will lead to rise in the real wages of abundant factor and the real wages of the scarce factor. This can be explained by the fact that trade liberalisation always involves trading off between gains for some and losses for others. Hence, there is significant trade-off between trade liberalisation and income distribution. The existing literature mostly supports the idea that there is a strong link between trade liberalisation and income distribution, however, few have denied the claim. In Brazil, increasing exposure to foreign trade has deteriorated income inequality, and that education and human capital are the key elements, which explained that (Carneiro and Arbache, 2003). Some other literatures are Dollar and Kraay (2002), Wade (2004)

On the other hand, a large number of literatures have recognized that trade liberalisation enhances inequality of income (as in Reynolds, 1987; Fischer, 2001). In another study, Borras (2007) argued that despite the fact that trade liberalisation increased productivity of Philippines' agricultural sector, the local farmers were unable to compete with imports from its neighbouring countries, hence trade liberalisation did not only fail to improve the standard of living in Philippines but has also increased poverty and income inequality. In a nutshell, the progress of globalisation worsens the situation of income inequality in Ghana, Korea and China as revealed by Ackah (2007), Mah (2003) and Mah (2013). Ezcurra and Rodriguez-Pose (2013), Beyer et al. (1999), Lin and Fu (2016), Raychaudhuri and De (2016), Bergh and Nilsson (2010), Kumar and Mishra (2008) also found similar relationship.

A study by Enowbi and Asungo (2015) "On financial liberalisation and income inequality", examined the effect of financial liberalisation on income inequality in 26 African countries over the period 1996 - 2010. After comparing previous and current responses and volatility of income inequality since the inception of liberalisation in these countries, the authors have employed panel data analysis in examining this relationship. They found that financial liberalisation measured by KAOPEN reduces income inequality in these selected African countries. Jaumotte and Papageorgiou (2013) have examined the impact of financial liberalisation on income inequality in a panel of 51 countries over a period of 23 years from 1981 to 2003. They found that financial liberalisation, direct foreign investment in particular is positively associated with income inequality. 
Bumann and Lensik (2013) revealed that liberalisation of the financial sector in the form of reserve requirement reduces inequality of income only when the level of liberalisation is not too high. However, for economies that have been liberalised financially, further liberalisation will have a negative effect on income distribution. In another study, Bumann and Lensik (2016) have found that capital account liberalisation positively affects income inequality, but the greater the financial depth, the lesser the effect of capital account liberalisation on income inequality. This could be explained by the fact that relationship between capital account liberalisation and income inequality varies by the level of financial depth. Quinn (1997) revealed strong and positive effect. Larrain (2013), Jayadev (2004) have found positive and negative effects respectively.

The most important literature gaps found by this study are the inability of the previous studies to include the rule of law in the estimations. Furthermore, studies previously done on this topic were more or less time series that focused on a single country for instance, studies done separately on the United States, Germany and India. This study aims to fill the gaps first of all by incorporating the rule of law in the model to be estimated and also through interacting between the variable with trade and financial liberalisation. Secondly, the study used a panel of 31 countries of Europe and applied the Pooled Mean Group (PMG). The current study, therefore, will be different from the previous one in terms of the variables used, the estimation techniques as well as the choice of countries or area of study.

\section{METHOD}

Based on the standard theory of international trade by Stopler and Samuelson and the research model of Lundberg,Squire (2003) and Barro (2000), this study applies the following model in estimating the relationship between the selected macroeconomic variables and income inequality:

$$
\begin{gathered}
I n q_{i t}=A_{i t} \theta+Y_{i}+\varepsilon_{i t} \\
(i=1 \ldots N ; \mathrm{t}=1 \ldots \ldots T)
\end{gathered}
$$

where Inq is a measure of income inequality for a country $i$ at time $t . A_{i t}$ is a vector of independent variable. The parameter $Y_{i}$ encompasses constant and individual specific variables and $\varepsilon_{i t}$ is an error term. The independent variables vary across time and countries, while the constant and specific individual variables do not vary over time. Based on the studies of Meschi and Vivarelli (2007) and Bumann and Lensik (2013), we modified equation (1) of this study as follows:

$$
I n q_{i t}=\alpha_{0 i}+\alpha_{1 i} T l_{i t}+\alpha_{2 i} F l_{i t}+\alpha_{3 i} R O L_{i t}+\alpha_{4 i} E d u_{i t}+\alpha_{5 i} R G D P C_{i t}+\mu_{i t}
$$

where Inq denotes income inequality measured by Gini Index, $T l$ denotes trade liberalisation measured by tariff reduction on primary and Manufactured goods, $F l$ denotes financial liberalisation measured by the Chin-Ito index, $R O L$ is a rule of law, $E d u$ is the average years of schooling of the population age 25 and above, (Barro \& 
Lee, 1996). The subscripts $i$ and $t$ referred to country and time, respectively. $\alpha_{1}, \alpha_{2}$ and $\alpha_{3}$ are parameters to be estimated and $\varepsilon$ is the error term.

In the equation (2) above, $\alpha_{1}$ is expected to carry positive sign to show that higher trade liberalisation is associated with rising inequality, (Meschi \& Vivarelli, 2007). $\alpha_{2}$ is also expected to have positive sign so that a higher level of financial liberalisation to induce income inequality, (Bumann \& Lensik, 2013). $\alpha_{3}$ has a negative sign as high quality of the rule of law tends to reduce the level of inequality. The increase in the level of average education attainment also reduces the disparity of income distribution, hence $\alpha_{4}$ is expected to carry negative sign.

A study by Chong and Calderon (2000) found that the context of institutional quality is associated with income distribution. Bhattacharyya (2012) also found that trade liberalisation is in some way associated with institutional quality. Therefore, if we introduce an interactive term of the rule of law and trade liberalisation as in the work of Brambor et al. (2006), we will then examine the relationship between trade liberalisation and income inequality in the presence of the rule of law. Furthermore, we apply the interactive term of the rule of law and financial liberalisation to also investigate the effects of financial liberalisation on income inequality in the presence of the rule of law. The model that incorporates the interactive terms is shown in the equation 3. The essence of this is to further deepen the explanation on whether the effect of trade liberalisation on income inequality still holds.

$$
\begin{aligned}
& I n q_{i t}=\alpha_{0 i}+ \alpha_{1 i} T l_{i t}+\alpha_{2 i} F l_{i t}+\alpha_{3 i} R O L_{i t} \\
&+\alpha_{4 i}(T l \times R O L)_{i t}+\alpha_{5 i}(F l \times R O L)_{i t}+\alpha_{6 i} E d u_{i t}+\alpha_{7 i} R G D P C_{i t} \\
&+\mu_{i t} \\
& i=1,2, \ldots, N ; t=1,2, \ldots, T
\end{aligned}
$$

In the equation (3) $\alpha_{1}, \alpha_{2}$ and $\alpha_{3}$ known as constitutive terms will also be interpreted, (Brambor et al., 2006). On the other hand, $\alpha_{4}$ and $\alpha_{5}$ are expected to profuse the effects of trade and financial liberalisation respectively and both are expected to be marginally positive. $\alpha_{6}$ is expected to carry negative sign to show an inverse relationship between average level of education and income inequality. Lastly, $\alpha_{7}$ is expected also to carry negative sign to show that an increase in real GDP decreases inequality level.

In this study, we adopt the Pooled Mean Group modelling approach proposed by Pesaranet al. (1999). We employed the PMG approach to establish long run relationship between the independent variables of trade liberalisation, financial liberalisation, Rule of law index, education attainment, economic growth and the dependent variable - income inequality. Some of the justifications for adopting this method include the following: firstly, the PMG has the capacity to estimate long run parameters irrespective of whether the variables are I(0), I(1) or both. Secondly, it allows short run dynamics in this type of specification to be data driven for each country in a panel while imposing common long run effects. Thirdly, it has the ability to estimate long run and short run dynamics relationship in a dynamic heterogeneous panel data. Based on these advantages of (PMG) estimator and according to Pesaran et al. (1999), the long run model as per equation (3) can be derived from the following short run ARDL model in the equation (4). Liew (2004) revealed that for small sample 
size, AIC outperforms SBIC in minimizing the probability of underestimation while maximizing the likelihood of recovering the true lag length. Taking the maximum lag equal to (1) based on AIC and assuming the ARDL, the equation can be given as below:

$$
\begin{aligned}
\operatorname{Inq}_{i t}=\beta_{0}+ & \sum_{i t=1}^{n} \beta_{1 i t} I n q_{i t-1}+\sum_{i t=1}^{n} \beta_{2 i t} T l_{i t-1} \\
& +\sum_{i t=1}^{n} \beta_{3 i t} F l_{i t}+\sum_{i t=1}^{n} \beta_{4 i t} R O L_{i t-1} \\
& +\sum_{i t=1}^{n} \beta_{5 i t}(T l \times R O L)_{i t-1}+\sum_{i t=1}^{n} \beta_{6 i t}(F l \times R O L)_{i t-1} \\
& +\sum_{i t=1}^{n} \beta_{7 i t} R G D P_{i t-1}+\sum_{i t=1}^{n} \beta_{8 i t} E d u_{i t-1} \\
& +\mu_{i t}
\end{aligned}
$$

To test for panel cointegration or estimate the long run relationship among the variables, the study tests the combine null hypothesis of no cointegration on the level variables in the Equation (4) against the alternative hypothesis, which suggests the existence of cointegration among variables. The presence of cointegration or otherwise is based on the outcome of seven different test statistics obtained via $O L S$ framework as per Equation (4). The P-value of majority of the test statistics has to be significant at $5 \%$ level to confirm the existence of cointegration, accept the alternative hypothesis and reject the null hypothesis. above,

From the Equation (4) we can have the long run model as per Equation (3)

$I n q_{i t}=\alpha_{0}+\alpha_{1} T l_{i t}+\alpha_{2} F l_{i t}+\alpha_{3} R O L_{i t}+\alpha_{4}(T l \times R O L)_{i t}+\alpha_{5}(F l \times R O L)_{i t}+$ $\alpha_{6} R G D P C_{i t}+\alpha_{7} E d u_{i t}+\mu_{i t}$

with $\quad \alpha_{0}=\frac{\beta_{0}}{1-\sum \beta_{1 i t}}, \alpha_{1}=\frac{\sum \beta_{2 i t}}{1-\sum \beta_{1 i t}}, \alpha_{2}=\frac{\sum \beta_{3 i 1}}{1-\sum \beta_{i t}}, \alpha_{3}=\frac{\sum \beta_{4 i t}}{1-\sum \beta_{1 i t}}, \alpha_{4}=\frac{\sum \beta_{5 i t}}{1-\sum \beta_{i t}}, \alpha_{5}=$ $\frac{\sum \beta_{6 i t}}{1-\sum \beta_{1 i t}}, \alpha_{6}=\frac{\sum \beta_{7 i t}}{1-\sum \beta_{1 i t}}$, and $\alpha_{7}=\frac{\sum \beta_{8 i t}}{1-\sum \beta_{1 i t}}$.

Using the residuals of the long run model, we can also infer cointegration from the following short run or error correction model,

$$
\begin{aligned}
\Delta I n q_{i t}=\theta_{0}+ & \sum_{i t=1}^{n} \theta_{1 i t} \Delta I n q_{i t-1}+\sum_{i t=1}^{n} \theta_{2 i t} \Delta T l_{i t-1} \\
& +\sum_{i t=1}^{n} \theta_{3 i t} \Delta F l_{i t}+\sum_{i t=1}^{n} \theta_{4 i t} \Delta R O L_{i t-1} \\
& +\sum_{i t=1}^{n} \theta_{5 i t} \Delta(T l \times R O L)_{i t-1}+\sum_{i t=1}^{n} \theta_{6 i t} \Delta(F l \times R O L)_{i t-1} \\
& +\sum_{i t=1}^{n} \theta_{7 i t} \Delta R G D P_{i t-1}+\sum_{i t=1}^{n} \theta_{8 i t} \Delta E d u_{i t-1}+\gamma E C T_{i t-1} \\
& +\varepsilon_{i t}
\end{aligned}
$$

where the error correction term, $E C T_{i t-1}$ is the residual of the long run model - Equation (3) 
$E C T_{t-1}=\mu_{i t-1}=i n q_{i t-1}-\left[\alpha_{0}+\alpha_{1} T l_{i t}+\alpha_{2} F l_{i t}+\alpha_{3} R O L_{i t}+\alpha_{4}(T l \times R O L)_{i t}+\right.$ $\left.\alpha_{5}(F l \times R O L)_{i t}+\alpha_{6} R G D P C_{i t}+\alpha_{7} E d u_{i t}\right]$

(6)

The sign $\gamma$ in the equation (5) is the error correction parameter implying the speed of adjustment. The negative sign (magnitude between 0 and 1) and significant $E C T_{i t-1}$ would imply that the model exhibits long run relationship between $I n q_{i t}$ and its determinants; $T l_{i t}, F l_{i t}, R O L_{i t},(T l \times R O L)_{i t},(F l \times R O L)_{i t}, R G D P C_{i t}$ and $E d u_{i t}$.

In line with the objective of this study, the important variables have been incorporated in the model. These include income inequality, economic growth, trade liberalisation, financial liberalisation, level of education attainment and rule of law. On this ground, annual data of income inequality measured by the Gini index, GDP per capita percentage growth rate, trade liberalisation were collected from World Development Indicators for the period of 1993 - 2014. Data on the rule of law was collected from the World Governance indicators. Data on the financial liberalisation and education attainment was collected from the Chin-Ito Index and the Penn World Table 8.1, respectively. To differentiate our work from the previous literature, rule of law index was used to capture the role it plays. Evidently, rule of law seems to have been neglected in the previous studies of the determinants of the rule of law.

\section{RESULTS AND DISCUSSION}

This study begins its estimation analysis with a panel unit root examination. The study implemented three types of panel unit root test; Levin et al. (2002), Im et al. (2003), and ADF Fisher test developed by Maddala-Wu (1999). All tests assumed a null hypothesis of non-stationary. Moreover, the three tests are Augmented DickeyFuller (ADF) test generalization from single time series to panel data (Baltagi, et al. 2005). The results of the entire unit root tests at first differenced are presented in the Table 1 below. 
Table 1 Results of the Panel Unit Root Tests

\begin{tabular}{|c|c|c|c|c|c|}
\hline \multicolumn{6}{|c|}{ Southern and Eastern Europe } \\
\hline \multirow[t]{2}{*}{ Variable } & \multirow[t]{2}{*}{ Statistics } & \multicolumn{2}{|c|}{ Level $\mathrm{I}(0)$} & \multicolumn{2}{|c|}{ First difference I(1) } \\
\hline & & Constant & $\begin{array}{l}\text { Constant \& } \\
\text { Trend }\end{array}$ & Constant & $\begin{array}{l}\text { Constant \& } \\
\text { Trend }\end{array}$ \\
\hline \multirow[t]{3}{*}{ Ineq } & $\mathrm{LLC} \mathrm{t}$ & $2.0527 * *$ & $1.5543 *$ & $15.683 * * *$ & $12.982 * * *$ \\
\hline & IPS W-stat & $1.9641 * *$ & 0.8569 & $14.595 * * *$ & $12.019 * * *$ \\
\hline & ADF Fisher & $45.759 * *$ & $40.196 *$ & $208.33 * * *$ & $159.15 * * *$ \\
\hline \multirow[t]{3}{*}{$F / l i b$} & LLC t & $6.1277 * * *$ & $2.9096 * * *$ & $7.4497 * * *$ & $8.9217 * * *$ \\
\hline & IPS W-stat & $1.9663 * *$ & 0.6979 & $7.7718 * * *$ & $6.3128 * * *$ \\
\hline & ADF Fisher & $48.473 * * *$ & 22.422 & $102.19 * * *$ & $82.017 * * *$ \\
\hline \multirow[t]{3}{*}{$T / l i b$} & $\mathrm{LLC} \mathrm{t}$ & $3.3484 * * *$ & $3.5447 * * *$ & $16.189 * * *$ & $15.371 * * *$ \\
\hline & IPS W-stat & $1.3064 *$ & $2.2811 * *$ & $16.197 * * *$ & $13.416 * * *$ \\
\hline & ADF Fisher & 30.769 & $45.579 * *$ & $230.88 * * *$ & $180.79 * * *$ \\
\hline \multirow[t]{3}{*}{$E d u c$} & LLC t & $9.9253 * * *$ & $1.6145^{*}$ & $12.243 * * *$ & $5.5407 * * *$ \\
\hline & IPS W-stat & $5.3879 * * *$ & $2.4265 * *$ & $8.8167 * * *$ & $7.4048 * * *$ \\
\hline & ADF Fisher & $174.09 * * *$ & $75.157 * * *$ & $295.99 * * *$ & $101.89 * * *$ \\
\hline \multirow[t]{3}{*}{$\operatorname{Rgdp}$} & LLC t & $6.6536 * * *$ & $6.5427 * * *$ & $16.455 * * *$ & $13.702 * * *$ \\
\hline & IPS W-stat & $5.4266^{* * *}$ & $5.6288 * * *$ & $15.136 * * *$ & $12.154 * * *$ \\
\hline & ADF Fisher & $77.852 * * *$ & $77.427 * * *$ & $218.52 * * *$ & $160.98 * * *$ \\
\hline \multirow[t]{3}{*}{$R O L$} & LLC t & 0.5271 & $2.1855 * *$ & $10.375^{* * *}$ & $9.7257 * * *$ \\
\hline & IPS W-stat & 1.2792 & 0.2465 & $8.4339 * * *$ & $7.1496 * * *$ \\
\hline & ADF Fisher & 21.184 & 30.209 & $114.42 * * *$ & $92.338 * * *$ \\
\hline \multicolumn{6}{|c|}{ Northern and Western Europe } \\
\hline \multirow[t]{3}{*}{ Ineq } & LLC t & $3.2698 * * *$ & $3.0240 * * *$ & $17.294 * * *$ & $14.375^{* * *}$ \\
\hline & IPS W-stat & $1.9183 * *$ & $2.1890 * *$ & $15.548 * * *$ & $12.915 * * *$ \\
\hline & ADFFisher & $46.015^{*}$ & $56.282 * *$ & $247.09 * * *$ & $190.31 * * *$ \\
\hline \multirow[t]{3}{*}{$F / l i b$} & $\mathrm{LLC} \mathrm{t}$ & $5.9585^{* * *} *$ & 0.0008 & $4.9645 * * *$ & $3.8889 * * *$ \\
\hline & IPS W-stat & $2.6833 * * *$ & 0.4301 & $5.6593 * * *$ & $4.3392 * * *$ \\
\hline & ADF Fisher & $33.295 * * *$ & 10.407 & $48.501 * * *$ & $35.356 * * *$ \\
\hline \multirow[t]{3}{*}{$T / l i b$} & $\mathrm{LLC} \mathrm{t}$ & $9.1684 * * *$ & $5.1756 * * *$ & $15.943 * * *$ & 17.491 **** \\
\hline & IPS W-stat & 3.2406 *** & $3.9626 * * *$ & 16.776*** & $16.127 * * * *$ \\
\hline & ADF Fisher & $62.654 * * *$ & $63.582 * * *$ & $268.87 * * *$ & $232.21 * * *$ \\
\hline \multirow[t]{3}{*}{$E d u c$} & LLC t & $7.7036^{* * * *}$ & 3.6964 & $1.4359 *$ & $1.3799 *$ \\
\hline & IPS W-stat & 3.5466 *** & 6.0118 & 0.3866 & 0.4350 \\
\hline & ADF Fisher & $72.246 * * *$ & 12.796 & $52.777 * *$ & 41.864 \\
\hline \multirow[t]{3}{*}{$\operatorname{Rgdp}$} & LLC t & $8.7041 * * *$ & $8.8002 * * *$ & $15.045 * * *$ & $10.772 * * *$ \\
\hline & IPS W-stat & 7.3313 *** & $7.0413 * * *$ & $15.174 * * *$ & $11.413 * * *$ \\
\hline & ADF Fisher & $114.73 * * *$ & $107.24 * * *$ & $245.57 * * *$ & $173.96 * * *$ \\
\hline$R O L$ & LLC t & 0.6967 & $1.7946 * *$ & $13.717 * * *$ & $7.5104 * * *$ \\
\hline
\end{tabular}




$\begin{array}{lllll}\text { IPS W-stat } & 0.0776 & 2.9633 * * * & 12.444 * * * & 8.4473 * * * \\ \text { ADF Fisher } & 39.334 & 61.005 * * * & 196.14 * * * & 127.72 * * *\end{array}$

Note: LLC t $=$ Levine, Lin and Chu test, IPS W-stat = Im, Pesaran and Shin Wald-statistics

From the above Table 1, all variables are stationary: some at the level, some at first difference while some at both. The unit root test on education level using Im, Pesaran and Shin test for Northern and Western Europe was non-stationary, all other tests (Levine, Lin and Chu and ADF Fisher) were stationary. However, owing to the powers of ADF Fisher and Levine et al. (2002) over Im et al. (2003), we conclude that there is absence of unit root in the variables, thus all variables should be considered as integrated of both order, I(1) and I(0).

To test for the existence of cointegration relationship among the variables, the unrestricted error correction model in the Equation 4 was estimated using Pedroni residual cointegration test. The result of the cointegration is presented in the Table 2 . The result suggests presence of cointegration between all variables with income inequality. Therefore, we accepted the alternative hypothesis and not the null hypothesis of no-cointegration.

Table 2 Results of panel cointegration test

\begin{tabular}{|c|c|c|c|c|}
\hline & \multicolumn{2}{|c|}{ Northern and Western Europe } & \multicolumn{2}{|c|}{ Southern and Eastern Europe } \\
\hline $\begin{array}{ll}\text { Pedroni residual } \\
\text { test }\end{array}$ & Panel Statistics & Group Statistics & Panel Statistics & $\begin{array}{l}\text { Group } \\
\text { Statistics }\end{array}$ \\
\hline Variance statistics & -2.4502 & ------ & -2.8458 & ------ \\
\hline Rho Statistics & 2.7475 & 3.5899 & 2.7002 & 4.7454 \\
\hline PP Statistics & $-4.7598 * * *$ & $-10.370 * * *$ & $-5.7939 * * *$ & $-4.5292 * * *$ \\
\hline ADF Statistics & $-3.2935 * * *$ & $-3.4220 * * *$ & $-5.8901 * * *$ & $-3.8041 * * *$ \\
\hline
\end{tabular}

Note: $* * *$ represents significant level of $1 \%$.

Table 2 contains a total of seven (7) outcomes, four (4) of the outcomes revealed that the variables are cointegrated by way of having their respective p-values less than 0.05. This means that there is a long-run relationship between our independent macroeconomic variables and the income inequality, and thus the need to further test for the long run coefficient.

Table 3 reported the results of the effect of trade liberalisation, financial liberalisation and other macroeconomic conditions that are assessed using PMG estimator after Hausman test was conducted, which chose PMG over MG estimator. In the Table 3 the estimated results showed that trade liberalisation has a positive and significant impact on income inequality in Northern and Western Europe, the coefficient of trade liberalisation revealed a positive sign, which means that the variable affects positively the level of income inequality. For instance, column 1 
reported that a 1 percent increase in trade liberalisation results in a 0.016 percent increase in the level of income inequality among people in those regions, and the impact is significant at 5\% level. This suggests that the Nordic and the Western countries of Europe identified as capital abundant countries compared to developing and other regions of the world encounter increase in inequality of income distribution when trade opens between them and the labour abundant countries. This result is in line with the results of Meschi and Vivarelli (2007) which revealed that higher trade liberalisation induces inequality of income distribution.

In Southern and Eastern Europe, the impact of trade liberalisation is also positive and significant on income inequality at $1 \%$ significance level, which is quite interesting to have such significant impact of trade liberalisation on income inequality. The only negative effect was not impressive as the significance level is $10 \%$. Therefore, the findings of this study corroborate the theory and earlier findings on the positive effect of trade liberalisation and income inequality. Hence, the study confirmed the positive relationship between the trade liberalisation and income inequality in Europe.

Similarly, the coefficient of financial liberalisation is positive, which means that it has a positive and significant impact on income inequality in Europe. All effects are significant at 1 percent significance level. For instance, column 1 in both regions reported that a 1 percent increase in financial liberalisation results in the increase of income inequality by 0.237 percent and 0.134 percent in Northern and Western Europe, and in Southern and Eastern countries of Europe respectively. These results validate the findings of Bumann and Lensik (2012) that higher level of financial liberalisation induces income inequality. Therefore, this study has confirmed that a higher level of financial development in Europe could lead to higher level of income inequality in Europe.

The coefficients in the column 4 of Northern and Western Europe and in the column 3 of the Southern and Eastern Europe have both reported a negative impact of the rule of law on income inequality in Europe. They revealed that a 1 percent increase in the quality of the rule of law will have a proportionate decrease in income inequality in these regions by 0.378 percent and 0.085 percent respectively, and the impacts are significant at $1 \%$ significance level. This suggests that better quality of the rule of law enhances equitable distribution of income in Europe.

This study also found that educational attainment both positively and significantly impacts income inequality in Europe. This is quite contrary to the expectations of this study, though, it is possible to have such positive impact of educational attainment on income inequality. This is because most economies especially the developed and the emerging ones have weak demand for less-educated workers and greater demand for more skilled workers, thereby expanding the income gap between workers with more and less educational attainment (Strauss 2011).

The real Gross Domestic Product (GDP) per capita growth, on the other hand, has reported a negative and significant impact on income inequality in Europe. This means that as the economies in Europe experienced growth, the level of inequality of income distribution declined. However, the percentage point of the decline in the inequality is quite low. For instance, column 1 reports that a 1 percent increase in 
economic growth results in a 0.004 percent decrease in income inequality in the Nordic and Western countries of Europe. While a 1 percent increase in economic growth of Southern and Eastern Europe results in 0.005 percent decrease in income inequality. This finding is in line with the expectations of this study.

The interactive terms of trade liberalisation and rule of law as well as financial liberalisation and rule of law, both conveyed negative coefficients. As mentioned in the previous chapter, the interaction of trade and financial liberalisation with the rule of law is to further deepen the explanations on the effect of trade and financial liberalisation on income inequality, under the strong rule of law. The interactive term of trade liberalisation and rule of law reports a negative and significant relationship with income inequality in the Nordic countries and Western Europe. A 1 percent increase in trade liberalisation accompanied by an equal percentage point increase in the rule of law results in 0.056 percent decrease in income inequality. In the Southern and Eastern Europe, on the other hand, a 1 percent increase in financial liberalisation accompanied by the same increase in the rule of law will decrease income inequality by 0.135 percent. All impacts are significant at $1 \%$ level. This suggests that good quality of the rule of law supports equitable distribution of income from trade.

Table 3 Result of the long run model and the error-correction adjustment

\begin{tabular}{|c|c|c|c|c|c|c|c|c|}
\hline \multirow[b]{2}{*}{ Coefficient } & \multicolumn{3}{|c|}{ Northern and Western Europe } & \multicolumn{4}{|c|}{ Southern and Eastern Europe } & \multirow[b]{2}{*}{ Column 4} \\
\hline & Column 1 & Column 2 & Column 3 & Column 4 & Column 1 & Column 2 & Column 3 & \\
\hline Constant & $\begin{array}{l}0.789 * * * \\
(0.142)\end{array}$ & $\begin{array}{l}0.840 * * * \\
(0.157)\end{array}$ & $\begin{array}{l}0.333 * * * \\
(0.051)\end{array}$ & $\begin{array}{l}0.241^{* *} \\
(0.103)\end{array}$ & $\begin{array}{l}1.659 * * * \\
(0.417)\end{array}$ & $\begin{array}{l}1.080 * * * \\
(0.357)\end{array}$ & $\begin{array}{l}1.122 * * * \\
(0.336)\end{array}$ & $\begin{array}{l}1.114 * * * \\
(0.429)\end{array}$ \\
\hline F/lib & $\begin{array}{l}0.237 * * * \\
(0.079)\end{array}$ & ------ & $\begin{array}{l}0.084 \\
(0.138)\end{array}$ & $\begin{array}{l}0.230 * * * \\
(0.077)\end{array}$ & $\begin{array}{l}0.134 * * * \\
(0.047)\end{array}$ & ------- & $\begin{array}{l}0.174 * * * \\
(0.039)\end{array}$ & $\begin{array}{l}0.029 \\
(0.030)\end{array}$ \\
\hline$T / l i b$ & $\begin{array}{l}0.016^{* *} \\
(0.007)\end{array}$ & $\begin{array}{l}0.023 * * * \\
(0.007)\end{array}$ & $\begin{array}{l}0.138 * * * \\
(0.028)\end{array}$ & $\begin{array}{l}0.577 * * * \\
(0.068)\end{array}$ & $\begin{array}{l}-0.004 \\
(0.006)\end{array}$ & $\begin{array}{l}0.0209 * * * \\
(0.003)\end{array}$ & $\begin{array}{l}0.020 * * * \\
(0.004)\end{array}$ & $\begin{array}{l}-0.012^{*} \\
(0.006)\end{array}$ \\
\hline $\operatorname{Rgdp}$ & $\begin{array}{l}-0.004 * * * \\
(0.0009)\end{array}$ & $\begin{array}{l}-0.004 * * * \\
(0.001)\end{array}$ & $\begin{array}{l}-0.001 \\
(0.001)\end{array}$ & $\begin{array}{l}-0.005 * * * \\
(0.001)\end{array}$ & $\begin{array}{l}-0.005 * * * \\
(0.001)\end{array}$ & $\begin{array}{l}0.002 * * \\
(0.001)\end{array}$ & $\begin{array}{l}-0.0016 \\
(0.001)\end{array}$ & $\begin{array}{l}-0.001 \\
(0.0004)\end{array}$ \\
\hline Educ & $\begin{array}{l}0.357 * * * \\
(0.047)\end{array}$ & $\begin{array}{l}0.306 * * * \\
(0.046)\end{array}$ & $\begin{array}{l}1.614 * * * \\
(0.164)\end{array}$ & $\begin{array}{l}1.178 * * * \\
(0.199)\end{array}$ & $\begin{array}{l}-1.197 * * * \\
(0.315)\end{array}$ & $\begin{array}{l}0.912 * * * \\
(0.136)\end{array}$ & $\begin{array}{l}0.851 * * * \\
(0.229)\end{array}$ & $\begin{array}{l}0.965 * * * \\
(0.121)\end{array}$ \\
\hline$R O L$ & $\begin{array}{l}0.088 \\
(0.060)\end{array}$ & $\begin{array}{l}0.238 * * * \\
(0.042)\end{array}$ & ------- & $\begin{array}{l}-0.378 * * * \\
(0.105)\end{array}$ & ------- & $\begin{array}{l}0.198 * * * \\
(0.042)\end{array}$ & $\begin{array}{l}-0.085 * * * \\
(0.030)\end{array}$ & ------- \\
\hline$R O L * F / l i b$ & ------- & ------ & $\begin{array}{l}0.096 \\
(0.080)\end{array}$ & ------ & ------- & ------- & ------- & $\begin{array}{l}-0.135^{* * *} \\
(0.021)\end{array}$ \\
\hline$R O L * T / l i b$ & ------ & ------ & $\begin{array}{l}-0.056^{* * * *} \\
(0.018)\end{array}$ & $\begin{array}{l}0.052 \\
(0.053)\end{array}$ & -------- & ------- & ------- & $\begin{array}{l}0.019 * \\
(0.011)\end{array}$ \\
\hline ECT & $\begin{array}{l}-0.516^{* * * *} \\
(0.084)\end{array}$ & $\begin{array}{l}-0.4791 * * * \\
(0.077)\end{array}$ & $\begin{array}{l}-0.444 * * * * \\
(0.063)\end{array}$ & $\begin{array}{l}-0.283^{* *} \\
(0.114)\end{array}$ & $\begin{array}{l}-0.367 * * * \\
(0.093)\end{array}$ & $\begin{array}{l}-0.449 * * * \\
(0.144)\end{array}$ & $\begin{array}{l}-0.469 * * * \\
(0.039)\end{array}$ & $\begin{array}{l}-0.486^{* * *} \\
(0.191)\end{array}$ \\
\hline HLRH & 0.984 & 0.9832 & 0.8881 & 0.9999 & 0.7165 & 0.9103 & 0.1014 & 1.000 \\
\hline Observation & 308 & 299 & 308 & 308 & 249 & 249 & 249 & 249 \\
\hline Countries & 17 & 16 & 17 & 17 & 14 & 14 & 14 & 14 \\
\hline
\end{tabular}

Note: L-R= Long run; ECA= Error correction adjustment; HLRH= Hausman long run homogeneity; 
$* * *, * *$ and $*$ are $1 \%, 5 \%$ and $10 \%$ significance levels respectively; standard errors in ()

The coefficients in the column 4 of the Northern and Western Europe and in the column 3 of the Southern and Eastern Europe have both reported a negative impact of the rule of law on income inequality. They revealed that a 1 percent increase in the quality of the rule of law will have a proportionate decrease in income inequality in these regions by 0.378 percent and 0.085 percent respectively, and the impacts are significant at $1 \%$ level. This suggests that better quality of the rule of law enhances equitable distribution of income in Europe.

This study also found that educational attainment both positively and significantly impacts income inequality in Europe. This is quite contrary to the expectations of this study, though, it is possible to have such positive impact of educational attainment on income inequality. This is because most economies especially the developed and the emerging ones have weak demand for less-educated workers and greater demand for more skilled workers, thereby expanding the income gap between workers with more and less educational attainment (Strauss 2011).

The real Gross Domestic Product (GDP) per capita growth, on the other hand, has reported a negative and significant impact on income inequality in Europe. This means that when economies in Europe experienced growth, the level of inequality of income distribution declined. However, the percentage point of the decline in inequality is quite low. For instance, column 1 reports that a 1 percent increase in economic growth results in a 0.004 percent decrease in income inequality in the Nordic and Western countries of Europe. While a 1 percent increase in economic growth of Southern and Eastern Europe results in 0.005 percent decrease in income inequality. This finding is in line with the expectations of this study.

\section{CONCLUSION}

Based on the estimated results of this study, trade and financial liberalisation are found to have a positive and significant relationship with income inequality in all the regions under study and the degree of their impact is almost the same across the regions. The rule of law index is found to have a negative impact when all variables are considered in the regression model. The interactive term of trade liberalisation and rule of law also revealed a negative impact on income inequality, indicating that the benefits from trade can best be distributed when the quality of the rule of law is at high level. Level of educational attainment is found to have a positive and significant impact on income inequality in Europe, which is said to oppose the expectations of this study. Although, it is possible to have a positive relationship between the level of education and income inequality in Europe as it is a continent with more developed and emerging countries whose demand for more educated workers is higher than less educated ones. The real GDP per capita growth has conveyed a negative and significant impact on income inequality in Europe. The magnitude of the impact is, of course, quite low in both areas of the study. In addition, high trade liberalisation in the form of tariff 
reduction in Europe provides huge benefits to the continent. The benefits, however, are no longer distributed evenly. Therefore, when designing and implementing policies towards boosting trade, the policymakers should also consider how the benefits are distributed. Otherwise, the policies only end up increasing disparity of income among the populace. Similarly, a financial development, which includes liberalising the financial system, causes income inequality in Europe. By implication, this might suggest that income inequality is also a consequence of financial development. Therefore, the policymakers should understand the level to which the system is liberalised. This is because a financial system that is not directed towards the lower class often creates more disparity in income distribution. These findings do not allow us making an extensive statement on other regions of the world as the data and the sample size is constricted to 17 countries in Northern and Western Europe. Therefore, further studies on other regions are hereby recommended.

\section{ACKNOWLEDGEMENTS}

We would like to thank the Faculty of Economics and Management, University Putra Malaysia for supporting this work both financially and academically. This research was supported in part by IPS grant (9539700) at the University of Putra Malaysia. We are also grateful to the anonymous reviewers of this work and to all those who contributed in one way or another to the successful completion of this work.

\section{REFERENCES}

Ackah, C. (2007). Trade Reforms, Human Capital and Poverty: A Pseudo Panel Ananlysis for Ghana. University of Nottingham: Centre for Research in Economic Development and International Trade School of Economics.

Archive: Income inequality statistics, Eurostat data 2015; European Statistics Explained.

Baltagi, B. H., Bratberg, E., \& Holmås, T. H. (2005). A panel data study of physicians' labor supply: the case of Norway. Health Economics, 14(10), 1035-1045.

Barro, R. J. (2000). Inequality and Growth in a Panel of Countries. Journal of economic growth, 5(1), 5-32.

Barro, R. J., Lee, J. W. (1996). International measures of schooling years and schooling quality. American Economic Review.

Bergh, A., \& Nilsson, T. (2010). Do liberalization and globalization increase income inequality?. European Journal of political economy, 26(4), 488-505.

Beyer, H. Rojas, P. Vergara, R. (1999). Trade liberalisation and wage inequality. Journal of Development Economics.

Bhattacharyya, S. (2012). Trade liberalization and institutional development Journal of Policy Modeling, 34(2), 253-269.

Borras Jr, S. M. (2007). 'Free market', export-led development strategy and its impact on rural livelihoods, poverty and inequality: The Philippine experience seen from a Southeast Asian perspective. jnl-title, 14(1), 143-175. 
Brambor, T., Clark, W. R., \& Golder, M. (2006). Understanding interaction models: Improving empirical analyses. Political analysis, 14(1), 63-82.

Bumann, S. Lensik, R. (2012). Financial liberalisation does not benefit them all. University of Groningen.

Bumann, S., \& Lensick, R. (2013). Financial Liberalization and income inequality: Channels and cross-country evidence. Working paper, University of Groningen, Department of Economics, Econometrics and Finance, The Netherlands.

Bumann, S., \& Lensink, R. (2016). Capital account liberalization and income inequality. Journal of International Money and Finance, 61, 143-162.

Carneiro, F. G., Arbache, J. S. (2003). Assessing the impacts of trade on poverty and inequality. Applied Economics Letters.

Chong A. Calderon C, (2000), Causality and Feedback between Institutional Measures and Economic Growth; Journal of Economics \& Politics, Vol.12, Issue 1, 2000.

Chinn, M. D. and H. Ito, The Chinn-Ito Index, http://web.pdx.edu/ ito/ChinnIto_website.htm, last updated 20 July 2017;

Dollar, D., Kraay, A. (2002) Spreading the Wealth. Foreign Affairs, 2002.

Enowbi Batuo, M., \& Asongu, S. A. (2015). The impact of liberalisation policies on income inequality in African countries. Journal of Economic Studies, 42(1), 68-100.

Evans, T. (2014). The impact of financial liberalisation on income inequality. International Journal of Labour Research.

Ezcurra, R. Rodriguez-Pose, A. (2013). Does economic globalisation affect regional inequality? A cross-country analysis. World Development.

Fischer, R. D. (2001). The evolution of inequality after trade liberalisation. Journal of Development Economics.

Fredriksen, K. B. (2012). Income inequality in the European Union.

Im, K. S., Pesaran, M. H., Shin, Y. (2003). Testing for unit roots in heterogeneous panels. Journal of Econometrics.

Overview of Inequality Trends, Key Findings and Policy Directions; OECD Report, 2015

International trade in goods: Eurostat Statistics Explained (2016)

Jaumotte, F., Lall, S., \& Papageorgiou, C. (2013). Rising income inequality: technology, or trade and financial globalization?. IMF Economic Review,61(2), 271-309.

Jayadev, A. (2004). The Impact of Capital Account Liberalisation on the Labour Share of Income. Political Economy Research Institute. 2004.

Kumar, U., \& Mishra, P. (2008). Trade liberalization and wage inequality: Evidence from India. Review of Development Economics, 12(2), 291-311.

Larrain, M. (2013). Capital Account Liberalisation and Wage Inequality: Evidence from Industrialised Countries. The International monetary Fund.

Levin, A., Lin, C. F., Chu, C. S. J. (2002). Unit root tests in panel data: asymptotic and finit-sample properties. Journal of Econometrics. 
Liew, V. K. Sen,(2004). Which Lag Length Selection Criteria Should We Employ?. Economics Bulletin, 3(33), 1-9.

Lin, F., \& Fu, D. (2016). Trade, Institution Quality and Income Inequality. World Development, 77, 129-142.

Lundberg, M., \& Squire, L. (2003). The simultaneous evolution of growth and inequality*. The Economic Journal, 113(487), 326-344.

Maddala, G. S., Wu, S. (1999). A comparative study of unit root tests with panel data and a new simple test. Oxford bulletin of Economics and Statistics.

Mah, J. S. (2003). A note on globalization and income distribution - the case of Korea, 1975-1995. Journal of Asian Economics, 14(1), 157-164.

Mah, J. S. (2013). Globalization, decentralization and income inequality: The case of China. Economic Modelling, 31, 653-658.

Meschi, E., \& Vivarelli, M. (2007). Trade openness and income inequality in developing countries.

Pesaran, M. H., Shin, Y., \& Smith, R. P. (1999). Pooled mean group estimation of dynamic heterogeneous panels. Journal of the American Statistical Association, 94(446), 621-634.

Quinn, D. (1997). The correlates of change in international financial regulation. American Political science review, 91(03), 531-551.

Raychaudhuri, A., \& De, P. (2016). Trade, infrastructure and income inequality in selected Asian countries: An empirical analysis. In International Trade and International Finance (pp. 257-278). Springer India.

Reynolds, B. L. (1987). Trade, employment, and inequality in post reform China. Journal of Comparative Economics.

Stolper, W. F., \& Samuelson, P. A. (1941). Protection and real wages. The Review of Economic Studies, 9(1), 58-73.

Strauss, S. (2011). The connection between education, income inequality, and unemployment. Huffington Post, 11, 02-11.

The Global Competitiveness Report, 2015-2016, Klaus Schwab, World Economic Forum

Wade, R. H. (2004). Is globalisation reducing poverty and inequality? World Development, 2004.

World Bank national accounts data, and OECD National Accounts data files. (2016)

World Bank national accounts data, and OECD National Accounts data files. (2016)

World Trade Report 2007: ISBN 978-92-870-3401-4 (English)

World Trade Report: International trade statistics 2002. 